\title{
KELAYAKAN MODUL PRAKTIK DASAR-DASAR AKUNTANSI BERBASIS SPREADSHEET DENGAN PENDEKATAN SIKLUS TRANSAKSI
}

\section{Feasibility of Spreadsheet-Based Basic Accounting Practice Module with Transaction Cycle Approach}

\author{
I Made Ariana \\ Jurusan Akuntansi, Politeknik Negeri Bali \\ Bukit Jimbaran, Kuta Selatan, Kabupaten Badung, Bali, 80364, Indonesia \\ madeariana@pnb.ac.id
}

Diterima:

29 Juni 2017,

direvisi :

16 Juli 2017,

Disetujui:

25 Juli 2017.

\begin{abstract}
The purpose of this research is to test and describe the feasibility of spreadsheet-based basic accounting practice module with transaction cycle approach. So far, there hasn't been any learning materials of spreadsheet-based basic accounting practice modul with transaction cycle approach available. The research method used is Borg \& Gall research and development model that is focused on the stage of module feasibility testing. The subjects of the test are experts and users. Qualitative data are analyzed by using qualitative descriptive analysis techniques, and quantitative data are analyzed by using the percentage analysis technique, which is comparing the number of answers to the number of ideal answers in 1 (one) item. Feasibility of spreadsheet-based basic accounting practice module with transaction cycle approach is determined by comparing the percentage of measured aspects to the scale of feasibility assessment scale. The conclusion is that the spreadsheet-based basic accounting practice module with transactional cycle approach is: (1) developed based on the spreadsheet-based accounting application with the transaction cycle approach, and (2) very feasible in term of its content, presentation, graph feature, and language. Therefore, it is recommended that the accounting lecturers use the spreadsheet-based basic accounting practice module with transaction cycle approach because it can help the learning process.
\end{abstract}

Keywords: module, accounting practice, spreadsheet, transaction cycle

ABSTRAK: Tujuan penelitian ini adalah menguji dan
mendeskripsikan kelayakan modul praktik dasar-dasar
akuntansi berbasis spreadsheet dengan pendekatan siklus
transaksi. Sejauh ini belum tersedia modul praktik dasar-dasar
akuntansi berbasis spreadsheet dengan pendekatan siklus
transaksi. Metode penelitian yang digunakan adalah penelitian
dan pengembangan (Research \& Development) model Borg \&
Gall yang difokuskan pada tahap pengujian kelayakan modul.
Subjek uji coba adalah kelompok ahli dan pengguna. Data
kualitatif dianalisis dengan teknik analisis kualitatif deskriptif;
sedangkan data kuantitatif dianalisis dengan menggunakan
teknik analisis persentase yaitu dengan membandingkan jumlah 
jawaban dengan jumlah jawaban ideal dalam 1 (satu) butir. Kelayakan modul praktik dasar-dasar akuntansi berbasis spreadsheet dengan pendekatan siklus transaksi ditentukan dengan membandingkan persentase aspek yang diukur dengan skala penilaian kelayakan. Simpulan penelitian ini adalah bahwa modul praktik dasar-dasar akuntansi berbasis spreadsheet dengan pendekatan siklus transaksi: (1) dikembangkan berdasarkan aplikasi akuntansi berbasis spreadsheet dengan pendekatan siklus transaksi; dan (2) sangat layak dari aspek isi, penyajian, kegrafikaan, dan kebahasaan. Oleh karena itu, disarankan kepada dosen pengampu mata kuliah akuntansi untuk menggunakan modul praktik dasar-dasar akuntansi berbasis spreadsheet dengan pendekatan siklus transaksi dalam pembelajaran karena bisa sangat membantu.

Kata Kunci: modul, praktik akuntansi, spreadsheet, siklus transaksi.

\section{PENDAHULUAN}

Pada Kurikulum Berbasis Kompetensi (KBK) Jurusan Akuntansi, beban SKS praktik lebih besar dibandingkan dengan beban SKS teori. Hal ini sesuai dengan Peraturan Presiden No. 8/2012 tentang Kerangka Kualifikasi Nasional Indonesia (KKNI) dan Undang-Undang No. 12 Tahun 2012, serta Standar Nasional Pendidikan Tinggi (SNPT). Pada Program Studi Diploma 3, beban SKS diatur dengan perbandingan 40\%-45\% teori dan 55\%-60\% praktik. Sementara itu, Program Studi Diploma 4 diatur dengan perbandingan 45\%-50\% teori dan 50\%-55\% praktik.

Praktik dasar-dasar akuntansi merupakan salah satu mata kuliah praktik yang umumnya diajarkan pada program studi diploma akuntansi. Setelah menyelesaikan mata kuliah ini, mahasiswa diharapkan mempunyai kemampuan menerapkan siklus akuntansi pada perusahaan jasa dan dagang, baik secara manual maupun berbasis komputer. Untuk itu, diperlukan modul manual dan berbasis komputer untuk memberikan keterampilan tentang penerapan siklus akuntansi secara manual, dan pengembangan serta penggunaan aplikasi siklus akuntansi berbasis komputer.

Pendekatan siklus transaksi digunakan dalam penyusunan bahan belajar di bidang akuntansi. Bahan belajar untuk mata kuliah dasar-dasar akuntansi, sistem informasi akuntansi, audit, dan paket program akuntansi lain umumnya disusun dengan pendekatan siklus transaksi. Pendekatan siklus transaksi juga digunakan dalam pengembangan modul praktik dasar-dasar akuntansi berbasis spreadsheet. Praktik dasar-dasar akuntansi manual relatif lebih mudah diperoleh dibandingkan dengan modul praktik dasar-dasar akuntansi berbasis spreadsheet.

Berdasarkan hasil survei terbatas di perpustakaan dan di toko-toko buku, diketahui bahwa belum tersedia modul praktik dasar-dasar akuntansi berbasis spreadsheet dengan pendekatan siklus transaksi. Oleh karena itu, perlu dikembangkan modul praktik dasar-dasar akuntansi berbasis spreadsheet dengan pendekatan siklus transaksi untuk meningkatkan pencapaian kompetensi mahasiswa Jurusan Akuntansi.

Pengembangan modul praktik dasardasar akuntansi berbasis spreadsheet dengan pendekatan siklus transaksi sangat diperlukan karena: (1) modul praktik dasardasar akuntansi berbasis spreadsheet dengan pendekatan siklus transaksi belum tersedia, baik di perpustakaan maupun tokotoko buku; (2) perlu disesuaikan dengan pendekatan penyusunan bahan belajar modul sebagaimana yang telah dilakukan untuk mata kuliah lainnya, seperti dasardasar akuntansi, sistem informasi akuntansi, audit, dan paket program akuntansi lain yang 
sudah disusun dengan pendekatan siklus transaksi; dan (3) sangat bermanfaat bagi dosen dan mahasiswa dalam pembelajaran praktik dasar-dasar akuntansi.

Penelitian ini bertujuan untuk mendeskripsikan pengembangan bahan belajar modul praktik dasar-dasar akuntansi berbasis spreadsheet dengan pendekatan siklus transaksi dan menguji kelayakannya. Bahan belajar merupakan bagian yang sangat penting dari suatu proses pembelajaran secara keseluruhan (Ramdani, 2012). Bahan belajar adalah bahan-bahan atau materi perkuliahan yang disusun secara sistematis untuk digunakan oleh dosen dan mahasiswa dalam proses perkuliahan (Unpad, 2011). Bahan belajar bisa berbentuk bahan cetak (hand out, buku, modul, lembar kerja siswa, brosur), audio visual (video/film, VCD), audio (radio, kaset, CD audio), visual (foto, gambar, model/maket), dan multimedia (CD interaktif, computer based, internet).

Modul merupakan salah satu bentuk bahan belajar berbasis cetakan yang dirancang untuk belajar mandiri (Kemdikbud, 2011). Modul adalah bahan belajar yang dikemas secara utuh dan sistematis yang dirancang untuk membantu peserta didik menguasai tujuan belajar yang spesifik (Daryanto, 2013). Modul dirancang untuk mencapai kompetensi yang diharapkan sesuai dengan tingkat kompleksitasnya (UII, 2009).

Tujuan penulisan modul adalah untuk (1) memperjelas dan mempermudah penyajian pesan agar tidak terlalu bersifat verbal; (2) mengatasi keterbatasan waktu, ruang, dan indra peserta didik dan sumber belajar; dan (3) dapat digunakan secara tepat dan bervariasi agar dapat meningkatkan motivasi dan gairah belajar peserta didik, mengembangkan kemampuan peserta didik dalam berinteraksi langsung dengan lingkungan dan sumber belajar lainnya, serta memberikan kesempatan kepada peserta didik untuk belajar mandiri sesuai kemampuan dan minatnya (Dikti, 2014; Universitas Brawijaya, 2010).

Modul bisa dikatakan baik dan menarik serta meningkatkan motivasi belajar apabila memiliki karakteristik: (1) self-instructional, yang berarti bahwa modul dapat dipelajari seseorang atau peserta didik mampu belajar secara mandiri, tidak tergantung pada pihak lain; (2) self-contained, yaitu seluruh materi pembelajaran dari satu unit kompetensi atau sub kompetensi yang dipelajari terdapat di dalam satu modul secara utuh; (3) stand alone (berdiri sendiri), di mana modul yang dikembangkan tidak tergantung pada media lain atau tidak harus digunakan bersamasama dengan media pembelajaran lain; (4) adaptive, berarti memiliki daya adaptif yang tinggi terhadap perkembangan ilmu dan teknologi; dan (5) user friendly, yang berarti bahwa modul dapat dipelajari dengan mudah. Setiap instruksi dan paparan informasi yang disajikan di dalam modul bersifat membantu atau mempermudah pemakainya (Daryanto, 2013; Widodo dan Jasmadi, 2008).

Pengembangan bahan belajar bentuk modul penting dilakukan dalam penerapan kurikulum berbasis kompetensi. Bahan belajar mampu mengatasi perbedaan karakteristik dan kemampuan belajar mahasiswa (Pujiati, 2007). Pengembangan bahan belajar meningkatkan pemahaman mahasiswa terhadap materi perkuliahan, dan pemahaman materi perkuliahan berhubungan secara signifikan dengan prestasi belajar mahasiswa (Trisnaningsih, 2007). Pengembangan bahan belajar meningkatkan hasil belajar mahasiswa (Harijanto, 2007).

Sistem komputerisasi dengan Microsoft Excel memberikan informasi yang lebih akurat, tingkat kesalahan yang lebih kecil, dan proses pengolahan data mulai dari posting sampai dengan laporan keuangan lebih cepat (Pamungkas dan Triandi, 2007; Triandi dan Stephanie, 2010). Pembelajaran laboratorium pengantar akuntansi menggunakan Microsoft Excel dapat meningkatkan pelaksanaan program belajar, aktivitas belajar, dan hasil belajar (Sugiarta, 2008).

Pada perusahaan besar, setiap transaksi yang terjadi diakuntansikan secara terpisah dalam siklus pendapatan, siklus pengeluaran, siklus produksi, dan siklus keuangan. Hasil proses dari empat siklus tersebut akan diproses lebih lanjut dalam 
siklus pelaporan keuangan (Samryn, 2012). Pengggunaan pendekatan siklus transaksi atau siklus akuntansi lebih konsisten dengan pendekatan database pada sistem akuntansi dibandingkan dengan pendekatan akun laporan keuangan. Siklus transaksi terdiri atas siklus pendapatan, siklus pembelian, siklus penggajian, siklus produksi, dan siklus keuangan (Perry dan Scheneider, 2005). Demikian juga halnya dalam hal audit atas laporan keuangan, audit dilakukan atas siklus pendapatan, siklus pengeluaran, siklus produksi dan siklus keuangan (Rama dan Jones, 2006). Beberapa pendapat tentang pengertian dan klasifikasi siklus transaksi dikemukakan dengan cara yang berbeda sesuai sudut pandang masing-masing, tetapi pada prinsipnya adalah sama.

Siklus pendapatan meliputi aktivitas yang terkait dengan penerimaan order, pengiriman barang, dan penerimaan kas. Siklus pembelian meliputi aktivitas yang terkait dengan order pembelian, penerimaan barang, dan pembayaran atas pembelian. Siklus penggajian meliputi aktivitas untuk menghitung pembayaran kotor, pengurangan, dan pembayaran bersih kepada karyawan. Siklus produksi meliputi aktivitas yang terkait dengan pengolahan bahan baku, tenaga kerja menjadi barang jadi (Perry dan Scheneider, 2005).

Aplikasi akuntansi berbasis spreadsheet yang sudah dikembangkan selama ini menggunakan pendekatan akun dan pendekatan jurnal. Aplikasi akuntansi berbasis spreadsheet dengan pendekatan akun dan pendekatan jurnal memiliki banyak keterbatasan. Oleh karena itu, perlu pengembangan aplikasi akuntansi berbasis spreadsheet dengan pendekatan siklus transaksi.

Pendekatan siklus transaksi digunakan untuk mengoptimalkan kemampuan aplikasi spreadsheet pada pemrosesan data akuntansi. Kelebihan aplikasi akuntansi berbasis spreadsheet dengan pendekatan siklus transaksi antara lain adalah input transaksi dilakukan dengan lebih mudah, pemrosesan informasi lebih cepat dan akurat, serta kuantitas dan kualitas laporan yang lebih baik (Ariana, 2016).

\section{METODA}

Pengembangan modul praktik dasardasar akuntansi diadaptasi dari model penelitian dan pengembangan (Research \& Development) Borg \& Gall yang dimodifikasi sesuai dengan pengembangan yang dilakukan. Penelitian ini fokus pada pengembangan modul praktik dasar-dasar akuntansi berbasis spreadsheet dengan pendekatan siklus transaksi dan pengujian kelayakannya.

Subjek uji coba atau validator pada penelitian ini adalah kelompok ahli dan kelompok pengguna. Kelompok ahli yaitu ahli materi dan pembelajaran akuntansi/komputer serta ahli desain modul. Ahli materi dan pembelajaran dalam penelitian ini adalah dosen akuntansi/komputer yang telah menempuh pendidikan minimal S2, dan telah berpengalaman mengajar akuntansi/ komputer. Ahli desain penyusunan modul dalam penelitian ini adalah dosen sastra Indonesia yang menguasai bidang pengembangan media pembelajaran, yang telah menempuh pendidikan minimal S2, dan berpengalaman dalam menyusun modul. Untuk uji pengguna, dilakukan kepada mahasiswa peserta kuliah praktik dasar-dasar akuntansi.

Data yang diperoleh dalam penelitian ini adalah data kuantitatif dan kualitatif. Data kuantitatif berupa angka yang diperoleh dari angket penilaian produk pengembangan yang disusun dengan skala Likert (skala bertingkat). Data kualitatif berupa komentar dan saran yang dituangkan dalam angket.

Komponen penilaian modul praktik dasardasar akuntansi mencakup kelayakan isi, kebahasaan, sajian, dan kegrafikaan. Komponen kelayakan isi mencakup (1) kesesuaian dengan Standar Kompetensi (SK) dan Kompetensi Dasar (KD); (2) kesesuaian dengan karakteristik; (3) kesesuaian dengan kebutuhan bahan belajar; (4) kebenaran substansi materi pembelajaran; (5) manfaat untuk penambahan wawasan; dan (6) kesesuaian dengan nilai moral dan nilainilai sosial. Komponen kebahasaan mencakup (1) keterbacaan; (2) kejelasan informasi; (3) kesesuaian dengan kaidah 
bahasa; (4) penggunaan bahasa Indonesia yang baik dan benar; dan (5) pemanfaatan bahasa secara efektif dan efisien (jelas dan singkat). Komponen penyajian mencakup (1) kejelasan tujuan (indikator) yang ingin dicapai; (2) urutan sajian; (3) pemberian motivasi, daya tarik; (4) interaksi (pemberian stimulus dan respons); dan (5) kelengkapan informasi.

Komponen kegrafikaan mencakup (1) penggunaan jenis dan ukuran huruf (font); (2) lay-out atau tata letak; (3) ilustrasi, gambar, foto, dan (4) desain tampilan (Kemdikbud: 2011).

Data kualitatif dianalisis dengan teknik analisis kualitatif deskriptif. Data kuantitatif dianalisis dengan menggunakan teknik analisis persentase, yaitu dengan membandingkan jumlah jawaban dalam 1 (satu) item dengan jumlah jawaban ideal dalam 1 (satu) item yang dinyatakan dalam persentase. Simpulan tentang kelayakan modul praktik dasar-dasar akuntansi berbasis spreadsheet dengan pendekatan siklus transaksi diketahui dengan cara membandingkan persentase aspek yang diukur dengan skala persentase penilaian kelayakan yang disajikan pada Tabel 1 berikut ini.

Tabel 1 Tingkat Kelayakan dan Kriteria Revisi

\begin{tabular}{ll}
\hline Rentang Nilai & Tingkat Kelayakan \\
\hline $82,3-95,0$ & Sangat layak, tidak perlu direvisi \\
$69,7-82,3$ & Layak, tidak perlu direvisi \\
$44,3-69,7$ & Cukup layak, perlu direvisi \\
$31,7-44,3$ & Kurang layak, perlu direvisi \\
$19,0-31,7$ & Sangat kurang layak, \\
& sangat perlu direvisi \\
\hline & Sumber: BSNP, 2009
\end{tabular}

\section{HASIL DAN PEMBAHASAN}

\section{Modul Praktik Dasar-dasar Akuntansi}

Modul praktik dasar-dasar akuntansi berbasis spreadsheet dengan pendekatan siklus transaksi dikembangkan berdasarkan aplikasi akuntansi berbasis spreadsheet dengan pendekatan siklus transaksi. Aplikasi akuntansi ini dapat digunakan untuk siklus akuntansi perusahaan jasa dan perusahaan dagang. Fasilitas pada aplikasi akuntansi ini terdiri atas (1) data awal yang meliputi informasi perusahaan, akun, vendor, pelanggan, persediaan; (2) siklus transaksi yang meliputi siklus pembelian, siklus penjualan, dan siklus kas; (3) jurnal yang meliputi jurnal khusus (pembelian, penjualan, penerimaan kas, pengeluaran kas) dan jurnal umum; (4) buku besar dan buku pembantu yang meliputi buku besar dan buku pembantu utang, piutang, serta persediaan; (5) neraca percobaan, neraca saldo, dan neraca lajur, (6) laporan keuangan yang meliputi laporan laba rugi dan pendapatan komprehensif lain, laporan posisi keuangan, laporan perubahan equitas, dan laporan arus kas; serta (7) neraca saldo penutupan.

Aplikasi akuntansi berbasis spreadsheet dengan pendekatan siklus transaksi memiliki perbedaan dengan aplikasi yang dibuat dengan pendekatan akun atau pendekatan jurnal. Pendekatan siklus transaksi diharapkan dapat mengatasi beberapa kekurangan pada aplikasi akuntansi berbasis spreadsheet dengan pendekatan akun atau pendekatan jurnal.

Pengembangan konsep modul mempertimbangkan hasil eksplorasi berbagai pedoman yang berkaitan dengan penyusunan modul di Jurusan Akuntansi. Tujuannya adalah agar modul yang dihasilkan sesuai dengan kebutuhan kompetensi mahasiswa, karakteristik mahasiswa, dan dosen pengampu mata kuliah praktik dasar-dasar akuntansi. Modul terdiri atas 3 buku, yaitu informasi perusahaan, petunjuk praktikum, dan penyelesaian. Informasi perusahaan berisikan informasi umum perusahaan dan informasi lain seperti identitas perusahaan, akun, vendor, pelanggan, dan persediaan. Informasi tersebut akan digunakan dalam proses pengolahan transaksi lebih lanjut.

Petunjuk praktikum terdiri atas 18 bab yang mencakup menu dan proteksi data, informasi perusahaan, daftar akun, neraca percobaan, daftar vendor, daftar pelanggan, persediaan, siklus pembelian, siklus penjualan, siklus kas, jurnal, buku besar, buku pembantu, neraca saldo, neraca lajur, laporan keuangan, daftar utang dan piutang, serta neraca saldo penutupan. 
Bagian penyelesaian berisikan penyelesaian atau kunci jawaban kasus. Penyelesaian ini berguna bagi dosen pengampu mata kuliah dalam mengawasi proses praktik dan menilai hasil praktik mahasiswa. Dalam proses, dosen dapat mengetahui kesalahan yang dilakukan mahasiswa sehingga bisa diarahkan dengan benar. Pada saat menilai hasil praktik, dosen menggunakan penyelesaian kasus ini sebagai standar yang harus dihasilkan mahasiswa.

Bagian penyelesaian berisikan (1) data awal yang meliputi informasi perusahaan, akun, vendor, pelanggan, dan persediaan; (2) siklus transaksi yang meliputi siklus pembelian, siklus penjualan, dan siklus kas; (3) jurnal yang meliputi jurnal khusus (pembelian, penjualan, penerimaan kas, pengeluaran kas), dan jurnal umum; (4) neraca percobaan yang meliputi neraca saldo dan neraca lajur; (5) laporan keuangan yang meliputi laporan laba rugi dan pendapatan komprehensif lain, Iaporan posisi keuangan, laporan perubahan equitas, dan laporan arus kas; dan (6) neraca saldo penutupan.

\section{Kelayakan Modul Praktik Dasar-Dasar Akuntansi Uji Ahli}

Pengujian kelayakan modul dilakukan oleh para ahli. Uji ahli meliputi uji ahli materi dan uji ahli media. Uji ahli materi menyangkut kelayakan isi dan kelayakan penyajian. Uji ahli media menyangkut kelayakan kegrafikaan dan kelayakan kebahasaan.

Pengujian kelayakan isi oleh ahli materi meliputi (1) kesesuaian dengan SK dan KD; (2) kesesuaian dengan karakteristik mata kuliah; (3) kesesuaian dengan kebutuhan bahan belajar; (4) kebenaran substansi materi pembelajaran; (5) manfaat untuk penambahan wawasan; dan (6) kesesuaian dengan nilai-nilai moral dan nilai-nilai sosial.

Berdasarkan pengujian ahli materi atas kelayakan isi modul dapat diketahui bahwa rata-rata persentase penilaian aspek isi adalah 90,83\%. Oleh karena itu, dari aspek isi dapat disimpulkan bahwa modul praktik dasar-dasar akuntansi berbasis spreadsheet dengan pendekatan siklus transaksi dinyatakan sangat layak dan tidak perlu direvisi. Secara visual, hasil uji kelayakan isi konsep modul oleh ahli materi disajikan pada Tabel 2 berikut ini.

Tabel 2 Hasil Uji Kelayakan Isi

\begin{tabular}{|c|c|c|c|c|c|c|c|c|}
\hline \multirow{2}{*}{ No. } & \multirow{2}{*}{ Aspek yang Diukst } & \multicolumn{4}{|c|}{ Adneman' Pilhan } & \multirow{2}{*}{$\mathrm{Jml}$} & \multirow{2}{*}{$\%$} & \multirow{2}{*}{ Penilaian } \\
\hline & & $\mathrm{SB}$ & $\mathrm{B}$ & $\mathrm{K}$ & SR & & & \\
\hline 1 & $\begin{array}{l}\text { Eesesurain dengan } \\
\text { SK dan KD }\end{array}$ & 4 & 1 & 0 & 0 & 19 & 95,00 & $\begin{array}{l}\text { Sangort } \\
\text { Layak }\end{array}$ \\
\hline 2 & $\begin{array}{l}\text { Kesesuaran dengan } \\
\text { kanalteristik maca } \\
\text { kuliah }\end{array}$ & 3 & 2 & 0 & 0 & 18 & 90,00 & $\begin{array}{l}\text { Sangent } \\
\text { Layzk }\end{array}$ \\
\hline 3 & $\begin{array}{l}\text { Keservaian dengan } \\
\text { bebunihan bahan } \\
\text { belajix }\end{array}$ & 3 & 2 & 0 & 0 & 18 & 90,00 & $\begin{array}{l}\text { Sungat } \\
\text { Layak }\end{array}$ \\
\hline 4 & $\begin{array}{l}\text { Kebenas an substamia } \\
\text { muteri pembelayman }\end{array}$ & 3 & 2 & 0 & 0 & 18 & 90,00 & $\begin{array}{l}\text { Sangent } \\
\text { Layzk }\end{array}$ \\
\hline 5 & $\begin{array}{l}\text { Nanfaser untdk } \\
\text { pernambehan wawasan }\end{array}$ & 3 & 2 & 0 & 0 & 18 & 90,00 & $\begin{array}{l}\text { Sangat } \\
\text { Layzk }\end{array}$ \\
\hline 8 & $\begin{array}{l}\text { Kesesuavim dengun } \\
\text { nilai moral, dev nilai- } \\
\text { milai social }\end{array}$ & 3 & 2 & 0 & 0 & 18 & 90,00 & $\begin{array}{l}\text { Sangent } \\
\text { Layzk }\end{array}$ \\
\hline & Rota-tata & & & & & & 90,85 & $\begin{array}{l}\text { Sunwat } \\
\text { Layak }\end{array}$ \\
\hline
\end{tabular}

Sumber: Dokumen tentang data yang diolah

Pengujian kelayakan penyajian oleh ahli materi meliputi (1) kejelasan tujuan (indikator) yang ingin dicapai; (2) urutan sajian; (3) pemberian motivasi; (4) daya Tarik; (5) interaksi (pemberian stimulus dan respon); dan (6) kelengkapan informasi. Selanjutnya, hasil uji kelayakan penyajian konsep modul oleh ahli materi disajikan pada Tabel 3 berikut ini.

Tabel 3. Hasil Uji Kelayakan Penyajian

\begin{tabular}{|c|c|c|c|c|c|c|c|c|}
\hline \multirow{2}{*}{ No. } & \multirow{2}{*}{ Aspek yang Diukur } & \multicolumn{4}{|c|}{ Alternatif Pilthan } & \multirow{2}{*}{ Jml. } & \multirow{2}{*}{$\%$} & \multirow{2}{*}{ Penilaian } \\
\hline & & SB & B & K & SK & & & \\
\hline 1 & $\begin{array}{l}\text { Kejelassn tujuan } \\
\text { (indikator) yang ingin } \\
\text { dicapai }\end{array}$ & 2 & 3 & 0 & 0 & 17 & 85,00 & $\begin{array}{l}\text { Sangat } \\
\text { Layak }\end{array}$ \\
\hline 2 & Urutan sajian & 3 & 2 & 0 & 0 & 18 & 90,00 & $\begin{array}{l}\text { Sangat } \\
\text { Layak }\end{array}$ \\
\hline 3 & Pemberian motivasi & 3 & 2 & 0 & 0 & 18 & 90,00 & $\begin{array}{l}\text { Sangat } \\
\text { Layak }\end{array}$ \\
\hline 4 & Daya tarik & 3 & 2 & 0 & 0 & 18 & 90,00 & $\begin{array}{l}\text { Sangat } \\
\text { Layak }\end{array}$ \\
\hline 5 & $\begin{array}{l}\text { Interaksi (pemberian } \\
\text { stimulus dan } \\
\text { respono) }\end{array}$ & 2 & 3 & 0 & 0 & 17 & 85,00 & $\begin{array}{l}\text { Sangat } \\
\text { Layak }\end{array}$ \\
\hline 6 & $\begin{array}{l}\text { Kelengkapan } \\
\text { informasi }\end{array}$ & 2 & 3 & 0 & 0 & 17 & 85,00 & $\begin{array}{l}\text { Sangat } \\
\text { Layak }\end{array}$ \\
\hline & Rata-rata & & & & & & 87,50 & $\begin{array}{c}\text { Sangat } \\
\text { Layak }\end{array}$ \\
\hline
\end{tabular}

Sumber: Dokumen tentang data yang diolah

Berdasarkan pengujian ahli materi atas kelayakan penyajian dapat diketahui bahwa rata-rata persentase penilaian aspek penyajian adalah $87,50 \%$. Oleh karena itu, dari aspek penyajian dapat disimpulkan bahwa modul praktik dasar-dasar akuntansi berbasis spreadsheet dengan pendekatan siklus 
transaksi dinyatakan sangat layak dan tidak perlu direvisi.

Pengujian kelayakan kegrafikaan oleh ahli media meliputi (1) penggunaan jenis dan ukuran huruf (font); (2) lay out atau tata letak; (3) ilustrasi, gambar, foto; dan (4) desain tampilan. Berdasarkan pengujian ahli media atas kelayakan kegrafikaan dapat diketahui bahwa rata-rata persentase penilaian aspek kegrafikaan adalah 83,33\%. Oleh karena itu, dari aspek kegrafikaan dapat disimpulkan bahwa modul praktik dasar-dasar akuntansi berbasis spreadsheet dengan pendekatan siklus transaksi dinyatakan sangat layak tetapi memerlukan perbaikan pada aspek gambar dan foto. Secara visual, hasil uji kelayakan kegrafikaan konsep modul oleh ahli media disajikan pada Tabel 4 berikut.

Tabel 4. Hasil Uji Kelayakan Kegrafikaan

\begin{tabular}{|c|c|c|c|c|c|c|c|c|}
\hline \multirow[t]{2}{*}{ No. } & \multirow{2}{*}{ Aspek yang Diukur } & \multicolumn{4}{|c|}{$\begin{array}{c}\text { Alternatif } \\
\text { Pilihan }\end{array}$} & \multirow{2}{*}{$\mathrm{Jml}$. } & \multirow[t]{2}{*}{$\%$} & \multirow{2}{*}{ Penilaiar } \\
\hline & & SB & B & $\mathrm{K}$ & SK & & & \\
\hline 1 & $\begin{array}{l}\text { Penggunaan jenis } \\
\text { dan ukuran huruf } \\
\text { (font) }\end{array}$ & 3 & 2 & 0 & 0 & 18 & 90,00 & $\begin{array}{l}\text { Sangat } \\
\text { Layak }\end{array}$ \\
\hline 2 & $\begin{array}{l}\text { Lay out atau tata } \\
\text { letak }\end{array}$ & 3 & 2 & 0 & 0 & 18 & 90,00 & $\begin{array}{l}\text { Sangat } \\
\text { Layak }\end{array}$ \\
\hline 3 & llustrasi & 2 & 3 & 0 & 0 & 17 & 85,00 & $\begin{array}{l}\text { Sangat } \\
\text { Layak }\end{array}$ \\
\hline 4 & Gambar & 0 & 5 & 0 & 0 & 15 & 75,00 & Layak \\
\hline 5 & Foto & 0 & 5 & 0 & 0 & 15 & 75,00 & Layak \\
\hline 6 & Desain tampilan & 2 & 3 & 0 & 0 & 17 & 85,00 & $\begin{array}{l}\text { Sangat } \\
\text { Layak }\end{array}$ \\
\hline & Rata-rata & & & & & & 83,33 & $\begin{array}{l}\text { Sangat } \\
\text { Layak }\end{array}$ \\
\hline
\end{tabular}

Sumber: Dokumen tentang data yang diolah

Pengujian kelayakan kebahasaan oleh ahli media meliputi (1) keterbacaan; (2) kejelasan informasi; (3) kesesuaian dengan kaidah bahasa; (4) penggunaan bahasa Indonesia yang baik dan benar; (5) pemanfaatan bahasa secara efektif dan efisien (jelas dan singkat).

Berdasarkan pengujian ahli media atas kelayakan kebahasaan dapat diketahui bahwa rata-rata persentase penilaian aspek kebahasaan adalah 88,00\%. Oleh karena itu, dari aspek kebahasaan dapat disimpulkan bahwa modul praktik dasar-dasar akuntansi berbasis spreadsheet dengan pendekatan siklus transaksi dinyatakan sangat layak dan tidak perlu direvisi. Secara visual, hasil uji kelayakan kebahasaan konsep modul oleh ahli media disajikan pada Tabel 5 berikut ini.
Tabel 5. Hasil Uji Kelayakan Kebahasaan

\begin{tabular}{|c|c|c|c|c|c|c|c|c|}
\hline \multirow[t]{2}{*}{ No. } & \multirow{2}{*}{ Aspek yang Diukur } & \multicolumn{4}{|c|}{$\begin{array}{c}\text { Alternatif } \\
\text { Plihan }\end{array}$} & \multirow{2}{*}{ JmI } & \multirow[t]{2}{*}{$\%$} & \multirow[t]{2}{*}{ Penilaian } \\
\hline & & $\overline{\text { SB }}$ & $\mathrm{B}$ & $\mathrm{K}$ & $5 K$ & & & \\
\hline 1 & Keterbacaan & 4 & 1 & 0 & 0 & 19 & 95,00 & $\begin{array}{l}\text { Sangat } \\
\text { Layak }\end{array}$ \\
\hline 2 & Kejalasan informersi & 2 & 3 & 0 & 0 & 17 & 85,00 & $\begin{array}{l}\text { Sangat } \\
\text { Layak }\end{array}$ \\
\hline 3 & $\begin{array}{l}\text { Kesesuaian } \\
\text { dengan kaidah } \\
\text { behasa }\end{array}$ & 3 & 2 & 0 & 0 & 18 & 90,00 & $\begin{array}{l}\text { Sangat } \\
\text { Layak }\end{array}$ \\
\hline 4 & $\begin{array}{l}\text { Bahersa } \\
\text { Indonesia/Bahasa } \\
\text { Inggris yang baik } \\
\text { dan benar }\end{array}$ & 2 & 3 & 0 & 0 & 17 & 85,00 & $\begin{array}{l}\text { Sangat } \\
\text { Layak }\end{array}$ \\
\hline 5 & $\begin{array}{l}\text { Pemanfastan } \\
\text { bahasa secara } \\
\text { bfoktif dan efisian }\end{array}$ & 2 & 3 & 0 & 0 & 17 & 85,00 & $\begin{array}{l}\text { Sangat } \\
\text { Layak }\end{array}$ \\
\hline & Rata-rata & & & & & & 88,00 & $\begin{array}{l}\text { Sangat } \\
\text { Layak. }\end{array}$ \\
\hline
\end{tabular}

Sumber: Dokumen tentang data yang diolah

\section{Uji Perseorangan}

Uji perseorangan terhadap modul dilakukan oleh 3 orang mahasiswa Semester II yang sedang mengikuti kuliah praktik dasardasar akuntansi. Ketiga mahasiswa yang dipilih adalah mahasiswa yang memperoleh nilai A pada mata kuliah pengantar akuntansi pada Semester I. Pemilihan ini didasarkan atas pertimbangan bahwa mahasiswa yang mempunyai prestasi akademik lebih baik umumnya lebih mampu memberikan penilaian terhadap modul yang digunakan. Berdasarkan pengujian perseorangan dapat diketahui bahwa rata-rata persentase penilaian pada uji perorangan adalah 90,00 \%. Oleh karena itu, dari aspek pengujian perseorangan dapat disimpulkan bahwa modul praktik dasar-dasar akuntansi berbasis spreadsheet dengan pendekatan siklus transaksi dinyatakan sangat layak dan tidak perlu direvisi. Secara visual, hasil uji kelayakan konsep modul pada uji perorangan disajikan pada Tabel 6 berikut ini.

Tabel 6. Hasil Uji Perorangan

\begin{tabular}{|c|c|c|c|c|c|c|c|c|}
\hline No. & Aspek yang Diukur & $\frac{\mathrm{All}}{\mathrm{SB}}$ & $\frac{\mathrm{ans}}{\mathrm{B}}$ & $\frac{\mathrm{F}^{\prime}}{\mathrm{K}}$ & $\frac{\text { Ihan }}{\text { SK }}$ & $\mathrm{mw}$. & \% & Penilaian \\
\hline 1 & Tampilan modul & 1 & 2 & 0 & 0 & 10 & 83,23 & $\begin{array}{l}\text { Sargat } \\
\text { Layk }\end{array}$ \\
\hline 2 & $\begin{array}{l}\text { Indkator } \\
\text { pambelaiaran }\end{array}$ & 2 & 1 & 0 & 0 & 11 & Q1,B7 & $\begin{array}{l}\text { Sangat } \\
\text { Layak }\end{array}$ \\
\hline 3 & lsi modul & 2 & 1 & 0 & 0 & 11 & 91,67 & $\begin{array}{l}\text { Sangat } \\
\text { Layak }\end{array}$ \\
\hline 4 & $\begin{array}{l}\text { Ketertankan pada } \\
\text { modul }\end{array}$ & 2 & 1 & 0 & 0 & 11 & 91,67 & $\begin{array}{l}\text { Sangat } \\
\text { Layak }\end{array}$ \\
\hline 5 & $\begin{array}{l}\text { Keterbantuan } \\
\text { dengan } \\
\text { pengounaan modul }\end{array}$ & 2 & 1 & 0 & 0 & 11 & 91,87 & $\begin{array}{l}\text { Serogt } \\
\text { Layak }\end{array}$ \\
\hline & Reta-rata & & & & & & 90,00 & $\begin{array}{l}\text { Serogt } \\
\text { Layak }\end{array}$ \\
\hline
\end{tabular}

Sumber: Dokumen tentang data yang diolah 
Tabel 7. Hasil Uji Kelompok Kecil

\begin{tabular}{|c|c|c|c|c|c|c|c|c|}
\hline No. & Aspek yang Diukur & $\frac{\text { Alle }}{\text { SBB }}$ & $\frac{m 60}{6}$ & $\frac{\mathrm{fPl}_{1}}{\mathrm{~K}}$ & $\frac{\text { han }}{\text { SK }}$ & $J \mathrm{w}$. & $\%$ & Penlaian \\
\hline 1 & Tampilan modul & 3 & 7 & 0 & 0 & 33 & 82,60 & $\begin{array}{l}\text { Sangat } \\
\text { Layak }\end{array}$ \\
\hline 2 & $\begin{array}{l}\text { Indkator } \\
\text { pembelaiaran }\end{array}$ & 6 & 4 & 0 & 0 & 36 & 50,00 & $\begin{array}{l}\text { Sangat } \\
\text { Layak }\end{array}$ \\
\hline 3 & lsi modul & 6 & 4 & 0 & 0 & 36 & 90,00 & $\begin{array}{l}\text { Sangat } \\
\text { Layak }\end{array}$ \\
\hline 4 & $\begin{array}{l}\text { Ketertarikan pada } \\
\text { modul }\end{array}$ & 7 & 3 & 0 & 0 & 37 & 92,50 & $\begin{array}{l}\text { Sangat } \\
\text { Layak }\end{array}$ \\
\hline \multirow[t]{2}{*}{5} & $\begin{array}{l}\text { Kenerbantuan } \\
\text { dengan penggunan } \\
\text { modul }\end{array}$ & 7 & 3 & 0 & 0 & 37 & 92,60 & $\begin{array}{l}\text { Sangat } \\
\text { Layak }\end{array}$ \\
\hline & Fata-rata & & & & & & 89,50 & $\begin{array}{l}\text { Sangat } \\
\text { Layak }\end{array}$ \\
\hline
\end{tabular}

Sumber: Dokumen tentang data yang diolah

Uji kelompok kecil dilakukan oleh 10 orang mahasiswa semester II yang sedang mengikuti kuliah praktik dasar-dasar akuntansi. Kesepuluh mahasiswa yang dipilih terdiri atas 3 orang mahasiswa yang memperoleh nilai $A$, 4 orang mahasiswa yang memperoleh nilai $B$, dan 3 orang mahasiswa yang memperoleh nilai $C$ pada mata kuliah pengantar akuntansi pada Semester I. Pemilihan ini didasarkan pada pertimbangan keterwakilan mahasiswa yang akan menggunakan modul. Selanjutnya, hasil uji kelayakan konsep modul pada uji kelompok kecil disajikan pada Tabel 7 berikut.

Berdasarkan pengujian kelompok kecil dapat diketahui bahwa rata-rata persentase penilaian pada uji kelompok kecil adalah $89,50 \%$. Oleh karena itu, dapat disimpulkan bahwa modul praktik dasar-dasar akuntansi berbasis spreadsheet dengan pendekatan siklus transaksi dinyatakan sangat layak dan tidak perlu direvisi.

Berdasarkan pengujian yang telah dilakukan, pada dasarnya tidak ada revisi yang harus dilakukan terhadap kelayakan isi, penyajian, kegrafikaan, dan kebahasaan dari modul praktik dasar-dasar akuntansi berbasis spreadsheet dengan pendekatan siklus transaksi. Namun apabila dilihat per item aspek yang diukur, masih ada aspek yang belum memperoleh penilaian maksimal. Atas kekurangan tersebut, telah dilakukan perbaikan seperlunya. Aspek ilustrasi, gambar, dan foto pada kelayakan kegrafikaan dinilai belum maksimal karena modul hanya menyertakan sedikit ilustrasi, gambar, dan foto.
Tabel 8. Hasil Uji Kelas

\begin{tabular}{|c|c|c|c|c|c|c|c|c|}
\hline & Aspek yang Divior & $\frac{\text { Alter }}{\text { Se }}$ & $\frac{n a 1^{n}}{\mathrm{\theta}}$ & $\frac{\mathrm{Fill}}{\mathrm{K}}$ & $\frac{\text { en }}{S K}$ & $J \mathbf{n d}$. & \% & Penilaian \\
\hline 1 & Tampilan modul & 16 & 35 & 0 & 0 & 169 & 92,84 & $\begin{array}{l}\text { Sangat } \\
\text { Layak }\end{array}$ \\
\hline 2 & $\begin{array}{l}\text { Indkator } \\
\text { pembelaiaran }\end{array}$ & 26 & 25 & 0 & 0 & 179 & 87,75 & $\begin{array}{l}\text { Sangat } \\
\text { Layak }\end{array}$ \\
\hline 3 & lsi modul & 28 & 23 & 0 & 0 & 181 & 88,73 & $\begin{array}{l}\text { Sangat } \\
\text { Layak }\end{array}$ \\
\hline 4 & $\begin{array}{l}\text { Kelertarikan pada } \\
\text { modul }\end{array}$ & 32 & 19 & 0 & 0 & 185 & 90,69 & $\begin{array}{l}\text { Sangat } \\
\text { Layak }\end{array}$ \\
\hline 5 & $\begin{array}{l}\text { Keterbantuan } \\
\text { dengan } \\
\text { pengounaan modul }\end{array}$ & 35 & 16 & 0 & 0 & 188 & 92,16 & $\begin{array}{l}\text { Sangat } \\
\text { Layak }\end{array}$ \\
\hline & Rata-rata & & & & & & 86,43 & $\begin{array}{l}\text { Sangat } \\
\text { Layak }\end{array}$ \\
\hline
\end{tabular}

Sumber: Dokumen tentang data yang diolah

\section{Uji Kelas}

Uji kelas dilakukan oleh mahasiswa dan dosen sebagai pengguna modul praktik dasar-dasar akuntansi berbasis spreadsheet dengan pendekatan siklus transaksi. Kelas yang digunakan dalam uji kelas adalah mahasiswa Kelas IIA dan Kelas IIB Akuntasi Manajerial. Respons mahasiswa tentang modul meliputi tampilan modul, indikator pembelajaran, isi modul, ketertarikan pada modul, dan kemudahan penggunaan modul. Selanjutnya, hasil uji kelayakan konsep modul pada uji kelompok kecil disajikan pada Tabel 8 berikut.

Berdasarkan pengujian kelas, dapat diketahui bahwa rata-rata persentase penilaian pada uji kelas adalah $88,43 \%$. Oleh karena itu, dari aspek pengujian kelas dapat disimpulkan bahwa modul praktik dasardasar akuntansi berbasis spreadsheet dengan pendekatan siklus transaksi dinyatakan sangat layak dan tidak perlu direvisi.

\section{SIMPULAN DAN SARAN}

Berdasarkan hasil dan pembahasan dapat disimpulkan bahwa modul praktik dasar-dasar akuntansi berbasis spreadsheet dengan pendekatan siklus transaksi dikembangkan berdasarkan aplikasi akuntansi berbasis spreadsheet dengan pendekatan siklus transaksi. Modul praktik dasar-dasar akuntansi berbasis spreadsheet dengan pendekatan siklus transaksi dinyatakan sangat layak, baik dari aspek isi atau konten, penyajian, kegrafikaan, maupun kebahasaan. 
Sebagai tindak lanjut dari simpulan hasil penelitian disarankan agar Jurusan Akuntansi menggunakan modul praktik dasar-dasar akuntansi berbasis spreadsheet dengan pendekatan siklus transaksi dalam pembelajaran karena modul ini dinyatakan sangat layak untuk digunakan dalam pembelajaran. Modul ini juga sangat membantu dosen pengampu mata kuliah dan peserta didik dalam pembelajaran praktik dasar-dasar akuntansi.

\section{PUSTAKA ACUAN}

\section{Buku}

Daryanto. 2013. Menyusun Modul Bahan Ajar untuk Persiapan Guru dalam Mengajar. Yogyakarta: Penerbit Gava Media.

Perry, James T. dan Scheneider, Gary P.. 2005. Building Accounting Systems Using Access 2003. USA: Thomson South-Western.

Rama, Dasaratha V. dan Jones Frederick L. 2006. Accounting Information Systems. USA: Thomson South-Western.

Samryn. 2012. Pengantar Akuntansi, Mudah Membuat Jurnal dengan Pendekatan Siklus. Jakarta: PT Raja Grafindo Persada.

\section{Jurnal/prosiding/disertasi/tesis/skripsi}

Ariana, I Made. 2016. Pengembangan Aplikasi Akuntansi dengan Microsoft Excel dengan Pendekatan Siklus Transaksi. Mataram. Jurnal Valid. Vol. 13, No. 2.

Harijanto, Mohammad. 2007. Pengembangan Bahan Ajar untuk Peningkatan Kualitas Pembelajaran Program Pendidikan Pembelajar Sekolah Dasar. Yogyakarta. Jurnal Didaktika, Vol. 2 No.1.

Pamungkas, Bambang dan Triandi. 2007. Telaahan Penerapan Sistem Informasi Akuntansi Berbasis Komputer Akuntansi (Menggunakan Microsoft Excel) dalam Penyajian Laporan Keuangan. Jurnal IImiah Kesatuan. Bogor. Volume 9 No. 2.

Pujiati. 2007. Bahan Ajar Praktikum Pengantar Akuntansi untuk Mahasiswa Jurusan Akuntansi. Yogyakarta. Jurnal Ekonomi \& Pendidikan. Volume 4 No. 2.
Ramdani, Yani. 2012. Pengembangan Instrumen dan Bahan Ajar untuk Meningkatkan Kemampuan Komunikasi, Penalaran, dan Koneksi Matematis dalam Konsep Integral. Semarang. Jurnal Penelitian Pendidikan. Volume 13 No. 1.

Sugiarta, I Komang. 2008. Metode Pembelajaran Laboratorium Pengantar Akuntansi Menggunakan Microsoft Excel pada Jurusan Akuntansi di Politeknik Negeri Bali. Singaraja. Jurnal Pendidikan dan Pengajaran Undiksa. No. 2.

Triandi dan Stephanie, Thresia. 2010. Penerapan Proses Akuntansi Menggunakan Microsoft Excel pada Perusahaan Sinar Harapan. Bogor. Jurnal Ilmiah Ranggagading. Volume 10 No. 2.

Trisnaningsih, 2007. Pengembangan Bahan Ajar untuk Meningkatkan Pemahaman Materi Mata Kuliah Demografi Teknik. Yogyakarta. Jurnal Ekonomi \& Pendidikan, Volume 4 Nomor 2.

\section{Lain-lain}

BSNP. 2009. Standar Penilaian Buku Teks Pelajaran. Sumber: www.bsnpindonesia.org. Diakses 31 Mei 2014.

Dikti. 2014. Pengembangan Bahan Ajar. Sumber: www.http://dikti.go.id/files/atur/ KTSP. Diakses tanggal 1 Maret 2014.

Kemdikbud. 2011. Penilaian Buku Teks Pelajaran. Jakarta: Balitbang Kemdikbud.

Universitas Brawijaya. 2010. Pedoman Umum Penulisan Bahan Ajar. Malang: Pascasarjana Unibra.

Universitas Islam Indonesia. 2009. Panduan Pembuatan Bahan Ajar Bagi Program Studi di Lingkungan Universitas Islam Indonesia. Yogyakarta: Universitas Islam Indonesia.

Universitas Padjadjaran. 2011. Pedoman Penulisan Buku Ajar. Bandung: Universitas Padjadjaran.

Widodo, S., Chomsin dan Jasmadi. 2008. Panduan Penyusunan Bahan Ajar Berbasis Kompetensi. Jakarta: PT. Elex Media Komputindo.

\section{Ucapan Terima Kasih}

Terima kasih kepada Direktorat Riset dan 
Pengabdian Masyarakat-Direktorat Jenderal Penguatan Riset dan Pengembangan Kementerian Riset, Teknologi, dan Pendidikan Tinggi yang telah memberikan pembiayaan sesuai dengan Surat Perjanjian Penugasan Pelaksanaan Program Penelitian Nomor: 093/SP2H/LT/DRPM/II/2016, tanggal 17 Februari 2016. 